\title{
Evaluating Ethylene Sensitivity and Exogenous Ethylene Impact on Early Growth of Grafted and Nongrafted Tomato Seedlings
}

\author{
Tricia Jenkins $^{1}$, Chieri Kubota ${ }^{2}$, Cary L. Rivard ${ }^{3}$, and \\ Eleni D. Pliakoni ${ }^{1}$
}

\begin{abstract}
ADDITIONAL INDEX WORDS. epinasty, propagation, Solanum lycopersicum, transportation

Summary. Ethylene sensitivity of grafted and nongrafted tomato (Solanum lycopersicum) seedlings with three to four true leaves was examined. The concentration of exogenous ethylene that produced symptoms was between 1 and $10 \mu \mathrm{L} \cdot \mathrm{L}^{-1}$ regardless of grafting. Symptoms of ethylene exposure included leaf epinasty, decreased maximal photochemical quantum yield of photosystem II $\left(F_{\mathrm{v}} / F_{\mathrm{m}}\right)$, and increased plant height (nongrafted only). Grafted plants maintained higher $F_{\mathrm{v}} / F_{\mathrm{m}}$ than nongrafted plants in response to higher ethylene concentrations. Ethylene-damaged plants showed comparable growth to the control plants 3 weeks after transplanting, but transplant quality was diminished as a result of ethylene exposure at high concentrations.
\end{abstract}

$\mathrm{G}$ rafted plants can provide resistance to soilborne diseases and abiotic stress, enhance plant vigor, and increase yields (Louws et al., 2010; Schwarz et al., 2010). The production of grafted tomato (Solanum lycopersicum) plants has increased in North America (Ertle, 2020). Grafted plants have greater value than nongrafted vegetable transplants; therefore, transplant quality needs to be maintained during the supply chain. One potential source of quality deterioration in commercial greenhouses, in storage facilities, and during shipping is exogenous and endogenous ethylene accumulation. Tomato is classified as highly sensitive to ethylene, but sensitivity can differ between cultivars and physiological stages (Edelman and

$\overline{\text { Received for publication } 14 \text { Sept. 2021. Accepted for }}$ publication 28 Dec. 2021

Published online 4 February 2022.

${ }^{1}$ Department of Horticulture and Natural Resources, Kansas State University, 22201 West Innovation Drive, Olathe, KS 66061

${ }^{2}$ Department of Horticulture and Crop Science, The Ohio State University, 202 Kottman Hall 2021 Coffey Road, Columbus, OH 43210

${ }^{3}$ Department of Horticulture and Natural Resources, Kansas State University, Olathe Horticulture Center $35230 \mathrm{~W}$ 135th Street, Olathe, KS 66061

E.D.P. is the corresponding author. E-mail: epliakoni@ksu.edu.

This is an open access article distributed under the CC BY-NC-ND license (https://creativecommons. org/licenses/by-nc-nd/4.0/).

https://doi.org/10.21273/HORTTECH04947-21
Jones, 2014). Dark-grown tomato seedlings exhibit the classic "triple response" when exposed to ethyleneincluding hypocotyl thickening, an exaggerated apical hook, and reduced hypocotyl elongation (Barry et al., 2001). The symptoms of ethylene damage on mature tomato plants can include flower senescence, bud and flower abscission, leaf chlorosis, and leaf epinasty (Edelman and Jones, 2014). Floral tissues are typically more sensitive to ethylene than vegetative tissue (Woltering, 1987). Leaf epinasty is the main symptom of ethylene exposure in vegetative tomato seedlings ( $4-5$ weeks old) and is typically reversable after the plants are removed from the ethylene environment (Edelman and Jones, 2014). However, high concentrations of ethylene $\left(10 \mu \mathrm{L} \cdot \mathrm{L}^{-1}\right)$ or long durations of ethylene exposure may also result in leaf abscission (Edelman and Jones, 2014; Woltering, 1987). In tomato transplants with visible first flowers, ethylene accumulation during a simulated long-distance transportation reached $118 \pm 10 \mathrm{nmol} \cdot \mathrm{mol}^{-1}(0.118 \pm$ $\left.0.01 \mu \mathrm{L} \cdot \mathrm{L}^{-1}\right)$ when shipped at $19^{\circ} \mathrm{C}$. The ethylene accumulation resulted in flower abortion and abnormal first truss developments (Kubota and Kroggel, 2011). It is less clear how younger grafted tomato transplants without visible flowers will perform after extended exposure to ethylene, or whether there is any difference in ethylene sensitivity between grafted and nongrafted tomato seedlings. The objectives of this study were 1) to determine the ethylene sensitivity of grafted and nongrafted tomato seedlings, and 2) to determine whether a prolonged (4-d) ethylene exposure affects transplant quality and early growth after transplanting.

\section{Materials and methods Plant materials}

Grafted and nongrafted tomato seedlings were grown in a greenhouse at the Kansas State University Olathe Horticulture Center (lat. $38.884347^{\circ} \mathrm{N}$, long. $\left.94.993426^{\circ} \mathrm{W}\right)$. 'Cherokee Purple' (Johnny's Selected Seeds, Winslow, ME) was selected for the scion and 'Maxifort' was selected for the rootstock (DeRuiter Seeds, St. Louis, MO). During seedling growth, the greenhouse temperatures were maintained at $27 \pm$ $5^{\circ} \mathrm{C}$ (day) and $17 \pm 2{ }^{\circ} \mathrm{C}$ (night). The seeds were sown in a germinating potting mix (Fafard Germinating Mix; Sun Gro Horticulture, Agawam, MA) in 12- $\times 12$-inch trays. About $10 \mathrm{~d}$ later, the seedlings were transplanted into 50 cell propagation trays filled with potting mix (Professional Growing Mix, Sun Gro Horticulture). When both the rootstock and scion seedlings had similar stem widths $(\approx 17 \mathrm{~d}$ later $)$, the seedlings were splice/tube-grafted and healed according to Rivard and Louws (2011). The healing chambers were located in the greenhouse and were covered with polyethylene film and $\mathbf{5 5} \%$ shadecloth. The plants remained in the healing chambers for $10 \mathrm{~d}$. After

\begin{tabular}{llll}
\hline $\begin{array}{l}\text { Units } \\
\text { To convert U.S. to SI, } \\
\text { multiply by }\end{array}$ & U.S. unit & SI unit & $\begin{array}{l}\text { To convert SI to U.S., } \\
\text { multiply by }\end{array}$ \\
\hline 0.3048 & $\mathrm{ft}$ & $\mathrm{m}$ & 3.2808 \\
2.54 & inch(es) & $\mathrm{cm}$ & 0.3937 \\
25.4 & inch $(\mathrm{es})$ & $\mathrm{mm}$ & 0.0394 \\
6.4516 & inch & $\mathrm{cm}^{2}$ & 0.1550 \\
28.3495 & $\mathrm{Oz}$ & $\mathrm{g}$ & 0.0353 \\
1 & $\mathrm{ppm}$ & $\mu \mathrm{L}^{2} \mathrm{~L}^{-1}$ & 1 \\
$\left({ }^{\circ} \mathrm{F}-32\right) \div 1.8$ & ${ }^{\circ} \mathrm{F}$ & ${ }^{\circ} \mathrm{C}$ & $\left({ }^{\circ} \mathrm{C} \times 1.8\right)+32$
\end{tabular}


healing, the plants were returned to the greenhouse and grown for $\mathrm{l}$ week before beginning the experiment. Nongrafted 'Cherokee Purple' seeds were sown 2 weeks after the grafted plants. Both grafted and nongrafted plants had three to four true leaves at the start of the experiment. The plants were transferred to the Postharvest Physiology Laboratory at Kansas State University Olathe for the ethylene exposure treatments.

\section{Expt. 1}

EXOGENOUS ETHYLENE TREATMENT. The grafted and nongrafted plants were placed randomly in four separate Plexiglas chambers, with 25 grafted and 25 nongrafted plants in each chamber. The chambers were subjected to one of the following exogenous ethylene treatment concentrations: 0 (control), $0.1,1$, and $10 \mu \mathrm{L} \cdot \mathrm{L}^{-1}$. The experimental design was most similar to a split-plot design, with ethylene treatment as the main effect and graft status of the plants as a subplot. The internal temperature in the chambers was $18.7 \pm 0.3^{\circ} \mathrm{C}$ and the relative humidity ranged from $96 \%$ to $99 \%$. The chambers remained on the laboratory bench and were exposed to a natural photoperiod near a window. The ethylene concentrations were confirmed two times each day with a gas chromatograph $(8610 \mathrm{C}$; SRI Instruments, Torrance, CA) equipped with a flame ionization detector and a 6 - $\mathrm{ft} \times 1 / 8$-inch stainless steel packed column (HayeSep D column, SRI Instruments).

Symptom evaluation. All measurements were made at day 0 immediately before the start of the experiment and once every $24 \mathrm{~h}$ during the 4 -d treatment period (days 1-4). After the measurements were made, the plants were returned to the treatment chambers and re-injected with ethylene to satisfy the treatment concentrations. Plant height was recorded on 15 nongrafted and 15 grafted plants from each treatment group. The remaining 10 grafted and 10 nongrafted plants from each treatment chamber were used to monitor maximum quantum efficiency of photosystem II $\left(F_{\mathrm{v}} / F_{\mathrm{m}}\right)$ and leaf epinasty. A handheld chlorophyll fluorometer equipped with leaf clips was used to measure $F_{\mathrm{v}} / F_{\mathrm{m}}$ on a single leaf from each replicate plant $(\mathrm{OS} 30 \mathrm{p}+$; Opti-
Sciences, Hudson, NH). The leaves were dark-adapted for $30 \mathrm{~min}$ before measurement. Symptoms of leaf epinasty were quantified with a protractor by measuring the leaf angle where the adaxial side of the third true leaf met the main stem during the 4 -d treatment period.

\section{Expt. 2}

SeEdLING GROWTH. The greenhouse experiment took place from 15 Apr. to 6 May. After the 4-d ethylene treatment, the plants were transported to the original greenhouse environment. Five days later, all plants were transplanted into nursery pots (6 inches in diameter $\times 5.6$ inches in height) with potting mix (Professional Growing Mix). The plants were arranged in a completely randomized design on the greenhouse bench and were fertilized weekly with an application of water-soluble fertilizer using $15 \mathrm{~N}-2.2 \mathrm{P}-12.5 \mathrm{~K}$ (Jack's Professional LX; JR Peters, Allentown, PA). The greenhouse was maintained at $27 \pm 5^{\circ} \mathrm{C}$ (day) and $17 \pm$ $2{ }^{\circ} \mathrm{C}$ (night). Six grafted and six nongrafted plants from each of the ethylene treatment groups were sampled destructively on the day of transplanting (day 0 ) and on days 7, 14, and 21. On each sampling day, stem length, total leaf area, and stem width were recorded. Stem length was measured from the soil surface to the apical meristem. The leaf area was measured with an area meter (LI-3100C; LI-COR, Lincoln, $\mathrm{NE}$ ). The stem diameter measurements were taken $1 \mathrm{~cm}$ above the cotyledons using a digital caliper (Digital Fractional Caliper; Husky Tools, Atlanta, GA). The shoot and root tissue of each sampled plant was dried at $60^{\circ} \mathrm{C}$ in a laboratory oven for $48 \mathrm{~h}$ to evaluate dry biomass. Day 0 measurements were considered an evaluation of transplant quality and the subsequent sampling days (days 7,14 , and 21) were collected to monitor early growth.

\section{Statistical analysis}

All data were analyzed using statistical software (SAS Studio 3.8; SAS Institute, Cary, NC). For the ethylene treatment experiment, $F_{\mathrm{v}} / F_{\mathrm{m}}$ and leaf epinasty (leaf angle) were analyzed using the MIXED procedure with $\mathrm{DDFM}=\mathrm{KR}$ in the MODEL statement and a repeated statement to account for repeated measures on the same plants. The fixed effects include ethylene treatments, graft status, and an ethylene treatment $\times$ graft status interaction term. For plant height, grafted and nongrafted plants were analyzed separately for the fixed effect of ethylene treatment with repeated measures because the plants had significantly different heights at the start of the experiment. Mean separation was carried out using Bonferroni's test at $P \leq 0.05$.

For the greenhouse experiment, growth measurements were analyzed separately for each sampling day. Grafted and nongrafted plants were also analyzed separately because of significant differences in the plant morphology measurements at the start of the experiment. The data were submitted to the GLIMMIX procedure. The mean separation was carried out with Bonferroni's test at $P \leq 0.05$.

\section{Results and discussion}

Symptoms of epinasty occurred in grafted and nongrafted plants within $24 \mathrm{~h}$ (day $\mathrm{l}$ ) when treated with $\mathrm{l}$ and $10 \mu \mathrm{L} \cdot \mathrm{L}^{-1}$ ethylene $[P \leq 0.0001$ (Fig. 1A)]. The degree of epinasty characterized the plants as being highly sensitive to ethylene (Edelman and Jones, 2014). The leaf angle after the first day of treatment was statistically similar between grafted and nongrafted plants and between the two ethylene concentrations levels ( 1 and $10 \mu \mathrm{L} \cdot \mathrm{L}^{-1}$ ), with an average angle increase of $57 \%$ from the initial day 0 conditions. This indicates that the point of ethylene saturation likely occurs around $1 \mu \mathrm{L} \cdot \mathrm{L}^{-1}$, because leaf epinasty was not significantly different at the higher concentration. The leaf angles were also similar between grafted and nongrafted plants on days 2 through 4 when treated at the two highest ethylene concentrations (Fig. 1A). Therefore, the graft status did not have a significant impact on this ethylene symptom. The plants treated with $0.1 \mu \mathrm{L} \cdot \mathrm{L}^{-1}$ were not statistically different from the control treatment, indicating that the concentration required to produce symptoms is between 0.1 and 1 $\mu \mathrm{L} \cdot \mathrm{L}^{-1}$ (Fig. 1A).

A decrease in $F_{\mathrm{v}} / F_{\mathrm{m}}$ can provide an early indication of plant stress from multiple abiotic stressors (Baker and Rosenqvist, 2004). Grafted and nongrafted plants treated with $\mathrm{l}$ and $10 \mu \mathrm{L} \cdot \mathrm{L}^{-1}$ ethylene declined in $F_{\mathrm{v}} / F_{\mathrm{m}}$ during the 4-d treatment, whereas those treated with $0.1 \mu \mathrm{L} \cdot \mathrm{L}^{-1}$ ethylene 

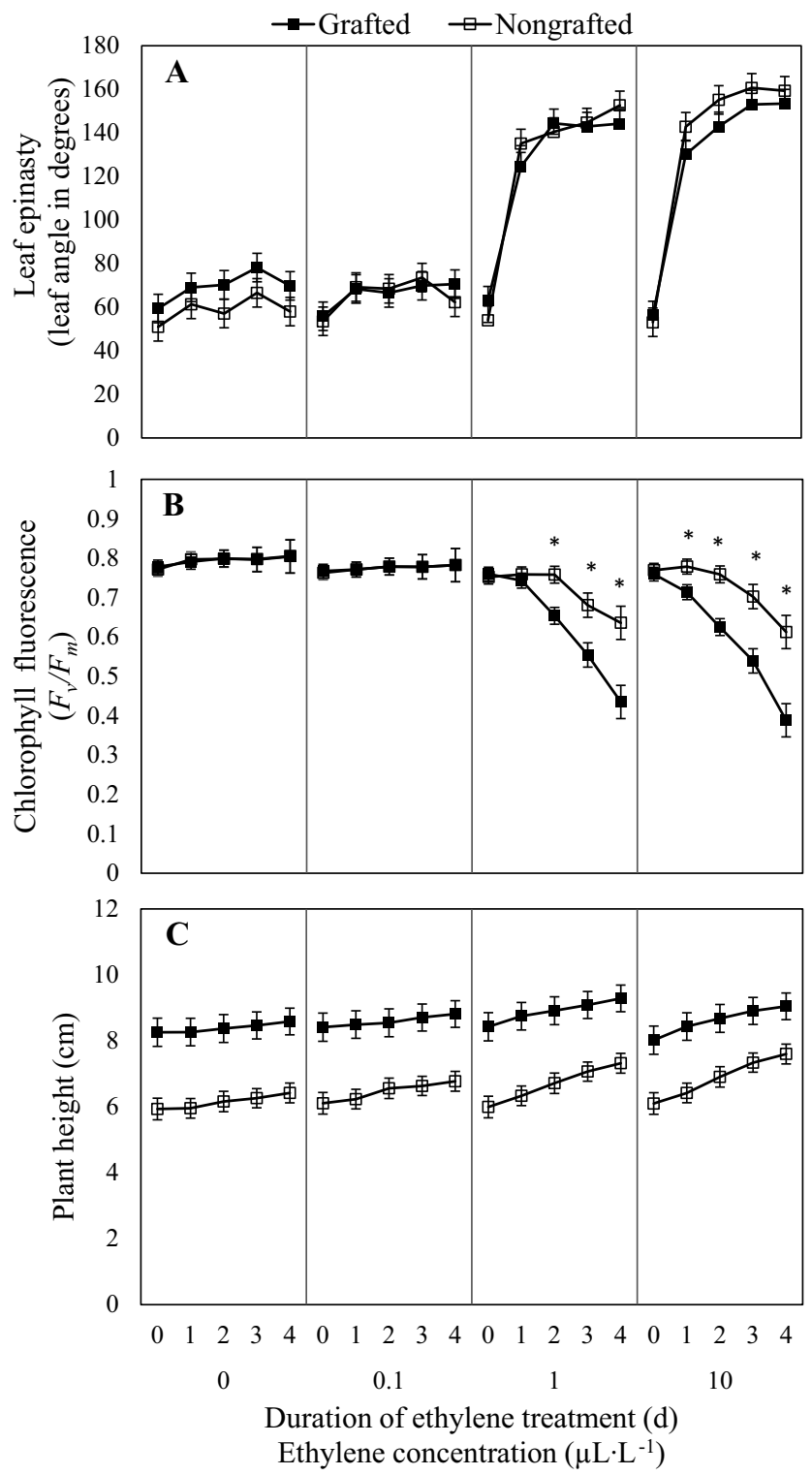

Fig. 1. (A) Leaf epinasty, (B) chlorophyll fluorescence $\left[F_{\mathrm{v}} / F_{\mathrm{m}}\right]$, and (C) plant height of grafted and nongrafted tomato seedlings treated with 0 (control), 0.1 , 1 , and $10 \mu \mathrm{L} \cdot \mathrm{L}^{-1}$ ethylene over a 4 -d treatment period. For leaf epinasty, the leaf angle was the angle where the adaxial side of the third true leaf met the main stem. All points represent means of plant replicates for each parameter $(n=10$ for leaf epinasty and chlorophyll fluorescence, $n=15$ for plant height). Error bars represent the $95 \%$ confidence interval of the means at the $\alpha=0.05$ significance level. For $F_{\mathrm{v}} / F_{\mathrm{m}}{ }^{*}=P \leq \mathbf{0 . 0 0 1}$ of pairwise comparison between graft and nongrafted data points on a given day; $1 \mu \mathrm{L} \cdot \mathrm{L}^{-1}=1 \mathrm{ppm}, 1 \mathrm{~cm}=0.3937$ inch.

and the control remained constant (Fig. 1B). In nongrafted plants, $F_{\mathrm{v}} / F_{\mathrm{m}}$ declined significantly $(P \leq 0.0001)$ by day 2 of the ethylene treatment at the two highest concentrations. However, the grafted plants did not have significant reductions in leaf $F_{\mathrm{v}} / F_{\mathrm{m}}$ values until day 4 of the ethylene treatment $[P \leq 0.0001$ (Fig. 1B)]. The total decline in $F_{\mathrm{v}} / F_{\mathrm{m}}$ in nongrafted plants treated with 1 and $10 \mu \mathrm{L} \cdot \mathrm{L}^{-1}$ at the end of the treatment period was 0.35 , have improved stress tolerance to secondary stress (Dong et al., 2013; Ghanbari and Sayyari, 2018; Zhang et al., 2018). For instance, tomato seedlings subjected to controlled drought stress had improved chilling tolerance, which was mediated by increased antioxidant enzyme activity, abscisic acid content, anthocyanin accumulation, potassium content, and proline content (Zhang et al., 2018). The grafted tomatoes in our experiment may have had better maintenance of photochemical efficiency during ethylene exposure as a result of the previous abiotic stress associated with grafting and wound healing.

Grafted plants did not change significantly in plant height across the 4-d treatment (Fig. IC). All nongrafted plants increased significantly in plant height from day 0 to day 4 $[P \leq 0.0001$ (Fig. 1C)]. The increase in plant height was $8.2 \%, 10.9 \%$, $22.1 \%$, and $24.6 \%$ for treatments of 0 , $0.1,1$, and $10 \mu \mathrm{L} \cdot \mathrm{L}^{-1}$ ethylene. Stem elongation is a common plant response to low irradiance, and this is likely the reason for stem elongation in the nongrafted plants (Kurepin and Pharis, 2014). However, the nongrafted plants treated with 1 and 10 $\mu \mathrm{L} \cdot \mathrm{L}^{-1}$ exogenous ethylene had significantly greater plant heights by day 4 compared with the control $(P \leq$ 0.05 and $P \leq 0.0001$, respectively). Exogenous ethylene typically results in the cessation of stem elongation (Abeles et al., 1992), but in our study we saw contrary results among the nongrafted tomatoes. Plants in flooded conditions exhibit ethylenemediated shoot elongation as an adaption response, and treatment of plants at saturating ethylene concentrations can mimic this response (Jackson, 2008). Stem elongation of tomato seedlings is a negative quality trait because growers prefer compact transplants with thick stems (Lee et al., 2010).

Within $24 \mathrm{~h}$ of being removed from the ethylene treatment, leaf necrosis of the two oldest leaves and abscission of cotyledons occurred in both grafted and nongrafted plants treated with $\mathrm{l}$ and $10 \mu \mathrm{L} \cdot \mathrm{L}^{-1}$ ethylene. All symptoms of leaf epinasty improved in the upper canopy within $24 \mathrm{~h}$. The plants with ethylene damage were of poorer quality at the time of transplanting, as observed by significantly lower leaf area, greater plant height, and 
Table 1. Plant growth measurements of grafted and nongrafted tomato seedlings after $4 \mathrm{~d}$ of exogenously applied ethylene at the concentrations of 0 (control), $0.1,1$, and $10 \mu \mathrm{L} \cdot \mathrm{L}^{-1}$. Each value represents the mean of measurements obtained from six grafted and six nongrafted plants at the time of transplanting in a greenhouse (day 0 ) and after 7,14, and $21 \mathrm{~d}$ of growth.

\begin{tabular}{|c|c|c|c|c|c|c|c|c|c|c|}
\hline \multirow[b]{3}{*}{ Plant measurements ${ }^{\mathrm{z}}$} & \multicolumn{5}{|c|}{ Grafted } & \multicolumn{5}{|c|}{ Nongrafted } \\
\hline & \multicolumn{4}{|c|}{ Ethylene $\left(\mu \mathrm{L} \cdot \mathbf{L}^{-1}\right)^{\mathrm{z}}$} & \multirow[b]{2}{*}{$P$ value ${ }^{\mathrm{y}}$} & \multicolumn{4}{|c|}{ Ethylene $\left(\mu \mathrm{L} \cdot \mathbf{L}^{-\mathbf{1}}\right)$} & \multirow[b]{2}{*}{$P$ value } \\
\hline & $\mathbf{0}$ & 0.1 & 1 & 10 & & 0 & 0.1 & 1 & 10 & \\
\hline \multicolumn{11}{|l|}{ Day $0^{\mathrm{x}}$} \\
\hline Leaf area $\left(\mathrm{cm}^{2}\right)$ & $42.53 \mathrm{a}^{\mathrm{w}}$ & $46.84 \mathrm{a}$ & $21.62 \mathrm{~b}$ & $21.05 \mathrm{~b}$ & $<0.0001$ & $50.82 \mathrm{a}$ & $59.11 \mathrm{~b}$ & $16.50 \mathrm{c}$ & $17.50 \mathrm{c}$ & $<0.0001$ \\
\hline Stem (mm) & 2.90 & 2.97 & 3.00 & 3.09 & NS & 3.21 & 3.27 & 3.28 & 3.45 & NS \\
\hline Root biomass (g) & 0.06 & 0.06 & 0.06 & 0.06 & NS & 0.09 & 0.11 & 0.09 & 0.08 & NS \\
\hline \multicolumn{11}{|l|}{ Day 7} \\
\hline Leaf area $\left(\mathrm{cm}^{2}\right)$ & 114.01 & 102.10 & 103.57 & 90.31 & NS & 133.62 & 151.48 & 116.67 & 107.08 & NS \\
\hline Stem $(\mathrm{mm})$ & 4.36 & 4.11 & 4.18 & 4.16 & NS & $4.92 \mathrm{a}$ & $4.82 \mathrm{a}$ & $4.61 \mathrm{ab}$ & $4.28 \mathrm{~b}$ & 0.001 \\
\hline Plant height $(\mathrm{cm})$ & 11.17 & 11.25 & 11.28 & 11.45 & NS & 9.70 & 9.98 & 10.67 & 10.52 & NS \\
\hline Shoot biomass (g) & $0.43 \mathrm{a}$ & $0.42 \mathrm{ab}$ & $0.37 \mathrm{ab}$ & $0.33 \mathrm{~b}$ & 0.0143 & $0.55 \mathrm{~b}$ & $0.63 \mathrm{a}$ & $0.46 \mathrm{c}$ & $0.43 \mathrm{c}$ & $<0.0001$ \\
\hline Stem (mm) & 6.35 & 6.47 & 6.58 & 6.61 & NS & $6.85 \mathrm{a}$ & $6.52 \mathrm{a}$ & $5.16 \mathrm{~b}$ & $6.03 \mathrm{a}$ & $<0.0001$ \\
\hline Plant height $(\mathrm{cm})$ & 15.67 & 16.77 & 16.40 & 16.84 & NS & 16.53 & 16.25 & 16.53 & 16.35 & NS \\
\hline Shoot biomass (g) & $1.97 \mathrm{a}$ & $1.92 \mathrm{a}$ & $1.62 \mathrm{~b}$ & $1.55 \mathrm{~b}$ & 0.0003 & $2.09 \mathrm{a}$ & $2.13 \mathrm{a}$ & $1.67 \mathrm{~b}$ & $1.84 \mathrm{~b}$ & $<0.0001$ \\
\hline Root biomass (g) & $0.33 \mathrm{~b}$ & $0.44 \mathrm{a}$ & $0.27 \mathrm{~b}$ & $0.33 \mathrm{~b}$ & 0.0005 & $0.53 \mathrm{~b}$ & $0.69 \mathrm{a}$ & $0.45 \mathrm{~b}$ & $0.50 \mathrm{~b}$ & $<0.0001$ \\
\hline \multicolumn{11}{|l|}{ Day 21} \\
\hline Leaf area $\left(\mathrm{cm}^{2}\right)$ & $667.73 \mathrm{~b}$ & $792.25 \mathrm{ab}$ & $681.48 \mathrm{~b}$ & $887.15 \mathrm{a}$ & 0.0054 & 771.25 & 877.97 & 839.99 & 859.65 & NS \\
\hline Stem (mm) & $6.51 \mathrm{bc}$ & $7.6 \mathrm{ab}$ & $6.0 \mathrm{c}$ & $7.71 \mathrm{a}$ & 0.0003 & $7.66 \mathrm{a}$ & $7.17 \mathrm{ab}$ & $6.52 \mathrm{~b}$ & $6.84 \mathrm{ab}$ & 0.0427 \\
\hline Plant height $(\mathrm{cm})$ & $25.78 \mathrm{ab}$ & $23.18 \mathrm{~b}$ & $28.6 \mathrm{a}$ & $23.32 \mathrm{~b}$ & 0.0001 & 26.93 & 24.75 & 26.3 & 25.85 & NS \\
\hline Shoot biomass $(\mathrm{g})$ & 5.08 & 5.75 & 4.84 & 5.73 & NS & 5.21 & 5.9 & 5.17 & 5.47 & NS \\
\hline Root biomass (g) & 0.62 & 0.59 & 0.52 & 0.59 & NS & 0.77 & 0.81 & 0.71 & 0.69 & NS \\
\hline
\end{tabular}

lower shoot biomass (nongrafted only) compared with the control plants (Table 1). Stem diameter and root biomass were not affected by ethylene treatment on day 0 , but the stem diameter of nongrafted plants treated with 1 and $10 \mu \mathrm{L} \cdot \mathrm{L}^{-1}$ remained lower than control plants for the subsequent three sampling periods (Table 1). Shoot biomass also remained lower than the control for grafted and nongrafted plants that experienced ethylene damage for the first 2 weeks of growth, which was likely a result of lower leaf necrosis in the ethylene-damaged plants. By day 21 , shoot biomass for grafted and nongrafted plants was comparable across all treatments. Interestingly, the leaf area of grafted and nongrafted plants treated with and 0.1 and $10 \mu \mathrm{L} \cdot \mathrm{L}^{-1}$ ethylene exceeded the control plants and those treated with $1 \mu \mathrm{L} \cdot \mathrm{L}^{-1}$ on day 14 (Table 1). This trend continued for grafted plants only on day 21 . It is unclear why the ethylene concentrations of 0.1 and $10 \mu \mathrm{L} \cdot \mathrm{L}^{-1}$ increased the leaf area 2 weeks after the exposure period, because ethylene typically inhibits leaf expansion (Abeles et al., 1992).

On day 7, the root biomass of the nongrafted plants treated with $10 \mu \mathrm{L} \cdot \mathrm{L}^{-1}$ ethylene was $35 \%$ lower than the control plants $(P \leq 0.001)$, indicating that the highest concentration of ethylene may have inhibited early root growth (Table 1). Inhibition in root growth is a common symptom of ethylene in dark-grown arabidopsis (Arabidopsis thaliana) seedlings (Stepanova et al., 2007), which has also been demonstrated in tomato (Negi et al., 2010). By day 14 , there was no suppression in root biomass of the nongrafted plants treated with $10 \mu \mathrm{L} \cdot \mathrm{L}^{-1}$ ethylene. The plants grafted to the interspecific rootstock did not have any significant reductions in root biomass as a result of the high-concentration ethylene treatments, which could suggest the root system was less sensitive to this ethylene response.

Although all ethylene-treated plants survived and early growth was not affected severely, plants treated with 1 and $10 \mu \mathrm{L} \cdot \mathrm{L}^{-1}$ ethylene had poorer overall visual quality because of lower leaf necrosis. Propagators of high-quality grafted tomato seedlings should take precautions to prevent extended ethylene exposure or the promotion of endogenous ethylene in greenhouse operations and in the postproduction supply chain. To our knowledge, this is the first experiment to examine the difference in ethylene sensitivity between grafted and nongrafted plants. These preliminary results suggest that grafted seedlings differ in response to exogenous ethylene compared with nongrafted plants, as indicated by better 
maintenance of $F_{\mathrm{v}} / F_{\mathrm{m}}$, and unaltered plant height. Further research needs to be conducted to confirm these results and understand the mechanisms of altered ethylene responses.

\section{Literature cited}

Abeles, F.B., P.W. Morgan, and M.E. Saltveit. 1992. Ethylene in plants. Academic Press, San Diego, CA.

Baker, N.R. and E. Rosenqvist. 2004. Applications of chlorophyll fluorescence can improve crop production strategies: An examination of future possibilities. J. Expt. Bot. 403:1607-1621, https://doi.org/10.1093/ jxb/erh196.

Barry, C.S., E.A. Fox, H. Yen, S. Lee, T. Ying, D. Grierson, and J.J. Giovannoni. 2001. Analysis of the ethylene response in the epinastic mutant of tomato. Plant Physiol. 127:58-66, https://doi.org/10.1104/ pp.127.1.58.

Dong, X., H. Bi, G. Wu, and X. Ai. 2013. Drought-induced chilling tolerance in cucumber involves membrane stabilisation improved by antioxidant system. Intl. J. Plant Prod. 7:67-80.

Edelman, N.F. and M.L. Jones. 2014. Evaluating ethylene sensitivity within the family Solanaceae at different developmental stages. HortScience 49:628-636, https://doi.org/10.21273/HORTSCI. 49.5.628.

Ertle, J.M. 2020. Effects of short-term chilling stress on seedling quality and posttransplanting growth of grafted and nongrafted watermelon. MS thesis, Ohio State Univ., Columbus. <http://rave.ohiolink. edu/etdc/view?acc_num=osu 159474277 $4066127>$.
Ghanbari, F. and M. Sayyari. 2018. Controlled drought stress affects the chillinghardening capacity of tomato seedlings as indicated by changes in phenol metabolisms, antioxidant enzymes activity, osmolytes concentration and abscisic acid accumulation. Scientia Hort. 229:167-174, https://doi. org/10.1016/j.scienta.2017.10.009.

Jackson, M.B. 2008. Ethylene-promoted elongation: An adaptation to submergence stress. Ann. Bot. 101:229-248, https://doi.org/10.1093/aob/mcm237.

Kubota, C. and M. Kroggel. 2011. Application of 1-MCP for long distance transportation of high quality tomato seedlings. Acta Hort. 898:279-286, https://doi. org/10.17660/ActaHortic.2011.898.34.

Kurepin, L.V. and R.P. Pharis. 2014. Light signaling and the phytohormonal regulation of shoot growth. Plant Sci. 229:280-298, https://doi.org/10.1016/ j.plantsci.2014.10.006.

Lee, J., C. Kubota, S.J. Tsao, Z. Bie, P. Echevarria, L. Morra, and M. Oda. 2010. Current status of vegetable grafting: Diffusion, grafting techniques, automation. Scientia Hort. 127:93-105, https://doi. org/10.1016/j.scienta.2010.08.003.

Louws, F.J., C.L. Rivard, and C. Kubota. 2010. Grafting fruiting vegetables to manage soilborne pathogens, foliar pathogens, arthropods and weeds. Scientia Hort. 127:127-147, https://doi.org/10.1016/ j.scienta.2010.09.023.

Negi, S., P. Sukumar, X. Liu, J.D. Cohen, and G.K. Muday. 2010. Genetic dissection of the role of ethylene in regulating auxindependent lateral and adventitious root formation in tomato. Plant J. 61:3-15, https://doi.org/10.1111/j.1365-313X. 2009.04027.x.
Rivero, R.M., J.M. Ruiz, E. Sánchez, and L. Romero. 2003. Does grafting provide tomato plants an advantage against $\mathrm{H}_{2} \mathrm{O}_{2}$ production under conditions of thermal shock? Physiol. Plant. 117:44-51, https:// doi.org/10.1034/j.1399-3054.2003.117 0105.x.

Rivard, C.L. and F.J Louws. 2011. Tomato grafting: A new tool for disease resistance and increased productivity. Sus. Agr. Res. Educ. (SARE) Agr. Inn. Bul. Ser. 12AGI2011.

Schwarz, D., Y. Rouphael, G. Colla, and J.H. Venema. 2010. Grafting as a tool to improve tolerance of vegetables to abiotic stresses: Thermal stress, water stress and organic pollutants. Scientia Hort. 127:162172, https://doi.org/10.1016/j.scienta. 2010.09.016.

Stepanova, A.N., J. Yun, A.V. Likhacheva, and J.M. Alonso. 2007. Multilevel interactions between ethylene and auxin in Arabidopsis roots. Plant Cell 19:2169-2185, https://doi.org/10.1105/tpc.107.052068.

Suchoff, D.H., C.C. Gunter, J.R. Schultheis, M.D. Kleinhenz, and F.J. Louws. 2018. Rootstock effect on grafted tomato transplant shoot and root responses to drying soils. HortScience 53:1586-1592, https://doi.org/10.21273/HORTSCI 13215-18.

Woltering, E.J. 1987. Effects of ethylene on ornamental pot plants: A classification. Scientia Hort. 31:283-294, https://doi. org/10.1016/0304-4238(87)90054-9.

Zhang, S., X. Xu, Y. Sun, J. Zhang, and C. Li. 2018. Influence of drought hardening on the resistance physiology of potato seedlings under drought stress. J. Integr. Agr. 17:336-347, https://doi.org/10.1016/ S2095-3119(17)61758-1. 